\title{
Non-obese adult onset diabetes with oral hypoglycemic agent failure: islet cell autoantibodies or reversible beta cell refractoriness?
}

J.R. Sá, R.C. Silva, F. Nasri, L.C.M. Aguade, L. Velloso, A.R. Chacra and S.A. Dib
Divisão de Endocrinologia, Escola Paulista de Medicina, Universidade Federal de São Paulo, São Paulo, SP, Brasil
Correspondence

S.A. Dib

Divisão de Endocrinologia

Departamento de Medicina, UNIFESP

Rua Botucatu, 740

Caixa Postal 20266

04034-970 São Paulo, SP

Brasil

Fax: +55-11-5579-6636

E-mail: sadib@endocrino.epm.br

Publication supported by FAPESP.

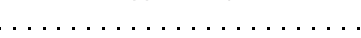

Received February 4, 2003

Accepted July 31, 2003

\begin{abstract}
Pancreatic $\beta$ cell function and insulin sensitivity, analyzed by the homeostasis model assessment, before and after 24 weeks of insulin therapy were studied and correlated with the presence of autoantibodies against $\beta$ cells (islet cell and anti-glutamic acid decarboxylase antibodies), in a group of 18 Brazilian lean adult non-insulin-dependent diabetes mellitus (NIDDM) patients with oral hypoglycemic agent failure (OHAF). Median fasting plasma glucose before and after insulin treatment was 19.1 and $8.5 \mathrm{mmol} / 1$, respectively $(\mathrm{P}<0.001)$; median $\mathrm{HbA} 1 \mathrm{c}$ was $11.7 \%$ before $v$ s $7.2 \%$ after insulin treatment $(\mathrm{P}<$ $0.001)$. Forty-four percent of the patients were positive $(\mathrm{Ab}+)$ to at least one autoantibody. Fasting $\mathrm{C}$-peptide levels were lower in $\mathrm{Ab}+$ than $\mathrm{Ab}$ - patients, both before (Ab+: $0.16 \pm 0.09$ vs $\mathrm{Ab}$-: $0.41 \pm 0.35 \mathrm{nmol} / \mathrm{l}$, $\mathrm{P}<0.003)$ and after insulin treatment $(\mathrm{Ab}+: 0.22 \pm 0.13 v s \mathrm{Ab}-: 0.44 \pm$ $0.24 \mathrm{nmol} / \mathrm{l}, \mathrm{P}<0.03$ ). Improvement of $\mathrm{H} \beta$ was seen in $\mathrm{Ab}$ - (median before: $7.3 v s$ after insulin therapy: $33.4 \%, \mathrm{P}=0.003$ ) but not in $\mathrm{Ab}+$ patients (median before: $6.6 v s$ after insulin therapy: 20.9\%). These results show that the OHAF observed in the 18 NIDDM patients studied was due mainly to two major causes: autoantibodies and $\beta$ cell desensitization. Autoantibodies against $\beta$ cells could account for $44 \%$ of OHAF, but $A b$ - patients may still present $\beta$ cell function recovery, mainly after a period of $\beta$ cell rest with insulin therapy. However, the effects of $\beta$ cell function recovery on the restoration of the response to oral hypoglycemic agents need to be determined.
\end{abstract}

\section{Introduction}

Oral hypoglycemic agent failure (OHAF) diabetes mellitus (T2DM) is heterogeneous regarding pathogenesis and biological markers. It is known that about 10 to $30 \%$ of newly diagnosed patients initially classified as T2DM have little or no glycemic response among all patients diagnosed with type 2
Key words

- Non-obese diabetes mellitus

- Oral hypoglycemic agent failure

- Non-insulin-dependent diabete mellitus

- Islet cell antibodies

- Beta cell function

- Insulin sensitivity to sulfonylurea (primary failure) $(1,2)$. In addition, after each year of treatment, approximately 5 to $10 \%$ of T2DM patients who have achieved fair or good metabolic control lose their responsiveness to sulfonylureas (secondary failure) $(1,2)$. Recently, the United Kingdom Prospective Diabetes Study (2) found a $7.3 \%$ annual incidence of secondary failure to sulfonylureas (chlorpropamide or 
glyburide) in newly diagnosed T2DM.

Two major factors can exert influence on $\beta$ cell function in patients initially classified as T2DM: the presence of autoantibodies against $\beta$ cells $(3,4)$ and chronic hyperglycemia (desensitization or glucotoxicity) (5). Glutamic acid decarboxylase antibodies (GAD65Ab) and islet cell antibodies (ICA) are useful humoral markers of both type 1 diabetes mellitus (T1DM; 6) and latent autoimmune diabetes of the adult $(7,8)$. The term glucose desensitization refers to a temporary physiological state of $\beta$ cell refractoriness to glucose stimulation induced by repeated or prolonged exposure to high concentrations of glucose. It is reversed in a time-dependent manner after restoration of normal glucose concentrations and implies involvement of an intrinsic and reversible alteration in stimulus-secretion coupling (5). The term glucose toxicity should be reserved for nonphysiological and potentially irreversible $\beta$ cell damage caused by chronic exposure to supraphysiological glucose concentrations. The $\beta$ cell damage is characterized by defective insulin gene expression (5). Chronic hyperglycemia may cause $\beta$ cell dysfunction due to oxidative stress activation of nuclear factor $\mathrm{\kappa B}$, which reduces insulin mRNA and insulin secretion and induces a proapoptotic event in $\beta$ cells (9). It has also been well established that glycemic control with insulin may restore $B$ cell sensitivity to glucose in some of the T2DM patients (10).

The aim of the present study was to determine the effect of 24 weeks of insulin therapy on $\beta$ cell function and insulin sensitivity and to correlate it with the presence of ICA in a group of lean adult apparent T2DM patients with OHAF.

\section{Patients and Methods}

\section{Patients}

Eighteen lean apparent T2DM adult patients (11 males/7 females, median age 45.5 years, median age at diagnosis 41 years, median time since T2DM diagnosis 30 months and mean \pm SD body mass index $(B M I)=22.1 \pm 3.0 \mathrm{~kg} / \mathrm{m}^{2}$ ) with OHAF, without previous insulin treatment and no ketoacidosis at diagnosis were studied. Primary and secondary OHAF were observed in $39 \%(7 / 18)$ and $61 \%(11 / 18)$ of them, respectively. Eleven patients had a positive family history of diabetes mellitus. They were recruited from the outpatient diabetic clinic at the Division of Endocrinology of Hospital São Paulo, UNIFESP, São Paulo, SP, Brazil. The patients were initially classified as T2DM according to the guidelines of the American Diabetes Association (11). The criteria used for defining an OHAF were a persistently higher than $11 \mathrm{mmol} / \mathrm{l}$ fasting blood glucose while receiving a maximum dose of first- or second-generation sulfonylureas, in the absence of active infectious disease, and a history of alcoholism or diabetes associated with other endocrine diseases. Primary OHAF was considered to be present when an adequate response to a maximal dose of oral hypoglycemic agents could not be achieved within at least 1 month of treatment (12). Secondary OHAF was defined as the loss of response to oral hypoglycemic agents after at least 6 months of good metabolic control (2).

\section{Design and treatment}

The study was conducted over a period of 24 weeks of diet plus insulin therapy. Oral hypoglycemic agents were withdrawn after the first clinical evaluation and blood samples were collected after a 12-h fast in order to determine fasting plasma glucose (FPG), fasting C-peptide (FCP), glycosylated hemoglobin (HbA1c), ICA and GAD65Ab values. A urine sample was also obtained for the determination of ketonuria. Patients received an individualized diet (50\% carbohydrates, $20 \%$ protein, $30 \%$ fat, preferentially mono- and polyunsaturated) and insulin therapy was 
started with intermediate action (NPH) insulin once or twice a day. The patients were followed for 24 weeks with medical appointments every 15 days. The same physicians performed all evaluations. The biochemical and hormonal measurements were repeated after 24 weeks. The Ethics Committee for Human Research of the University Hospital approved the protocol and written informed consent was obtained from all patients.

\section{Assays}

FPG was determined by the glucose-oxidase method, with normal values ranging from 3.8 to $6.4 \mathrm{mmol} / \mathrm{l}$. HbAlc was determined by affinity chromatography (13), with normal values ranging from 2.6 to $5.6 \%$. FCP was determined by radioimmunoassay (14) using the anti-C peptide K6 antibody (Novonordisk Laboratory, Gentofte, Denmark). The normal values for this assay ranged from 0.15 to $0.52 \mathrm{nmol} / 1$ and the lowest detection limit was $0.01 \mathrm{nmol} / \mathrm{l}$. Ketonuria was determined by the semiquantitative nitroprusside method. ICA were measured by the immunoperoxidase method with protein A-peroxidase (15) using cryostatic sections of Wistar rat pancreas as substrate. Two independent observers read the sections, prepared in duplicate, on a doubleblind basis. GAD65Ab were measured by a radiobinding assay using $\left[{ }^{35} \mathrm{~S}\right]$-recombinant GAD65. This assay had a $6.7 \%$ interassay coefficient of variation. The results are reported as GAD65Ab index and values higher than one were considered to be positive (16). Beta cell function and insulin sensitivity were calculated from pairs of FPG and FCP by the homeostasis model assessment (HOMA) using a computer program obtained from Dr. Jonathan C. Levy, Diabetes Research Laboratories, Radcliff Infirmary, Oxford, UK (17).

\section{Statistical analysis}

Statistical analyses were performed us- ing the SigmaStat software. Data are reported as the mean $\pm \mathrm{SD}$ or median. The statistical difference between two variables was calculated by the Mann-Whitney U-test or by Kruskal-Wallis one-way analysis of variance on ranks test. For paired data, Wilcoxon's test was used. Spearman's rank test $(\mathrm{rS})$ was used to determine the correlation between variables. A P value less than 0.05 was considered to be significant.

\section{Results}

There was a positive correlation between the chronological age at diabetes diagnosis and the time to develop OHAF ( $\mathrm{rS}=0.47$, $\mathrm{P}<0.05)$. The patients' BMI before insulin therapy was $22.1 \pm 3.0 \mathrm{~kg} / \mathrm{m}^{2}$ (median: 22.6 $\mathrm{kg} / \mathrm{m}^{2}$, range: $14.8-26.7 \mathrm{~kg} / \mathrm{m}^{2}$ ) and did not change significantly after insulin treatment.

Ketoacidosis was not present in any of these patients when diabetes was diagnosed but $55.5 \%$ of them had ketonuria at our first laboratory evaluation. Pre-insulin treatment FPG and $\mathrm{HbA} 1 \mathrm{c}$ were $20.1 \pm 6.6 \mathrm{mmol} / \mathrm{l}$ (median: $19.1 \mathrm{mmol} / \mathrm{l}$ ) and $12.1 \pm 2.3 \%$ (median: $11.7 \%$ ), respectively. After insulin treatment, these values were $9.7 \pm 4.5 \mathrm{mmol} / \mathrm{l}$ (median: $8.5 \mathrm{mmol} / \mathrm{l}$ ) and $7.6 \pm 2.2 \%$ (median: 7.2\%), respectively ( $\mathrm{P}<0.001$ for FPG and $\mathrm{HbA} 1 \mathrm{c})$. Before insulin therapy the basal FCP levels of these patients ranged from 0.07 to $1.34 \mathrm{nmol} / \mathrm{l}$, with a mean of $0.30 \pm$ $0.29 \mathrm{nmol} / 1$ and a median of $0.23 \mathrm{nmol} / \mathrm{l}$. After 24 weeks of insulin treatment, FCP levels increased to $0.34 \pm 0.22 \mathrm{nmol} / 1$, but this difference was not significant. There was a correlation between FCP values before and after insulin treatment $(\mathrm{rS}=0.84$, $\mathrm{P}<0.0001$ ); FCP before and after insulin treatment also correlated with time since diabetes diagnosis (before: $\mathrm{rS}=0.67, \mathrm{P}<$ 0.003 and after: $\mathrm{rS}=0.74, \mathrm{P}<0.0001)$ and with BMI (before: $\mathrm{rS}=0.53, \mathrm{P}<0.03$ and after: $\mathrm{rS}=0.49, \mathrm{P}<0.05$ ).

In the group of OHAF patients as a whole, insulin treatment improved $B$ cell function 
(before insulin: HOMA B: 6.6\%, 1.8-261.7 and after insulin: $31.9 \%, 5.9-135.4 ; \mathrm{P}=$ 0.008 ). Insulin sensitivity also tended to improve (before insulin: HOMA S: $51.9 \%, 3.9$ 440.0 and after insulin: $131.5 \%, 32.3-1354.0$; $\mathrm{P}=0.070$ ).

Forty-four percent of the patients were positive for at least one of the ICA studied. ICA were present in $27.8 \%(5 / 18)$ of the patients and GAD65Ab in 33.3\% (5/15). Autoantibody-positive and -negative patients were analyzed separately (Table 1). ICAand/or GAD65Ab-positive patients were younger than autoantibody-negative patients $(38.5 \pm 15.2$ years, median $=30.5$ years $v s$ $49.7 \pm 12.4$ years, median $=50$ years; $\mathrm{P}=$ $0.07)$. The time since diabetes diagnosis was shorter for autoantibody-positive patients
$(16.2 \pm 29.9$ months, median $=2.5$ months $v s$ $54.6 \pm 40.2$ months, median $=48$ months; $\mathrm{P}<0.002$ ). The prevalence of primary failure was higher in autoantibody-positive $(75 \%)$ than in autoantibody-negative $(10 \%)$ patients $(\mathrm{P}<0.05)$. In contrast, secondary failure was more frequent in autoantibodynegative $(90 \%)$ than in autoantibody-positive $(25 \%)$ patients $(\mathrm{P}<0.05)$. No significant differences were found concerning the presence of ketonuria, FPG and $\mathrm{HbA} 1 \mathrm{c}$ between patients with or without autoantibodies. FCP levels were lower in autoantibody-positive than in autoantibody-negative patients both before $(0.16 \pm 0.09$ vs $0.41 \pm 0.35 \mathrm{nmol} / \mathrm{l}$; $\mathrm{P}$ $<0.003)$ and after insulin treatment $(0.22 \pm$ 0.13 vs $0.44 \pm 0.24 \mathrm{nmol} / \mathrm{l} ; \mathrm{P}<0.03$ ) (Figure 1). No difference in FCP values was ob-

Table 1. Clinical and laboratory characteristics of diabetic patients with oral hypoglycemic agent failure according to positivity for ICA and/or GAD65Ab.

\begin{tabular}{lcc}
\hline & $A b+$ & $A b-$ \\
\hline$N$ & $8(44.4 \%)$ & $10(55.6 \%)$ \\
Age (years) & $38.5 \pm 15.2$ & $49.7 \pm 12.4$ \\
Sex (male/female) & $4 / 4$ & $7 / 3$ \\
Time since diagnosis (months) & $16.2 \pm 29.9$ & $54.6 \pm 40.2^{*}$ \\
Primary failure (\%) & 75 & $10^{*}$ \\
Secondary failure (\%) & 25 & $90^{*}$ \\
BMI (kg/m²) & $20.9 \pm 2.9$ & $23.0 \pm 2.9$ \\
Ketonuria (positive/negative) & $5 / 3(62.5 \%$ pos.) & $5 / 5(50 \%$ pos.) \\
FPG (mmol/l) before insulin Tx & $17.1 \pm 5.5$ & $22.5 \pm 6.6$ \\
FPG (mmo/l) after insulin Tx & $9.3 \pm 4.4^{* *}$ & $10.1 \pm 4.7^{* *}$ \\
HbA1c (\%) before insulin Tx & $12.4 \pm 1.9$ & $12.0 \pm 2.7$ \\
HbA1c (\%) after insulin Tx & $7.8 \pm 2.6^{* *}$ & $7.3 \pm 2.0^{* *}$ \\
FCP (nmol/l) before insulin Tx & $0.16 \pm 0.09$ & $0.41 \pm 0.35^{*}$ \\
FCP (nmol/l) after insulin Tx & $0.22 \pm 0.13$ & $0.44 \pm 0.24^{*}$ \\
ICA+ & $5 / 8(62.5 \%)$ & 0 \\
GAD65Ab+ & $5 / 8(62.5 \%)$ & 0 \\
ICA and GAD65Ab+ & $2 / 8(25 \%)$ & 0 \\
ICA or GAD65Ab+ & $8 / 8(100 \%)$ & 0 \\
HOMA ß (\%, median and range) before insulin Tx & $6.6(1.8-262.7)$ & $7.3(2.2-29.2)^{* *}$ \\
HOMA ß (\%, median and range) after insulin Tx & $20.9(5.9-79.2)$ & $33.4(8.0-135.4)^{* *}$ \\
HOMA S (\%, median and range) before insulin Tx & $115.5(3.9-440.0)$ & $50.0(17.9-168.0)$ \\
HOMA S (\%, median and range) after insulin Tx & $149.7(97.7-1354.0)$ & $92.1(32.3-475.6)^{*}$ \\
\end{tabular}

$\mathrm{Ab}+=$ autoantibody-positive patients; $\mathrm{Ab}-=$ autoantibody-negative patients; $\mathrm{BMI}=$ body mass index; $\mathrm{FCP}=$ fasting C-peptide; FPG = fasting plasma glucose; GAD65Ab+ = glutamic acid decarboxylase antibodies; $\mathrm{HbA1c}=$ glycosylated hemoglobin; HOMA $\beta$ and HOMA S = $B$ cell function and insulin sensitivity, respectively, as analyzed by the homeostasis model assessment; ICA = islet cell antibodies; $\mathrm{Tx}=$ treatment. Data are reported as means $\pm \mathrm{SD}$.

${ }^{*} \mathrm{P}<0.05, \mathrm{Ab}$ - compared to $\mathrm{Ab}+\left(\right.$ Mann-Whitney $\mathrm{U}$-test); ${ }^{*} \mathrm{P}<0.05$, before versus after insulin treatment (Wilcoxon's test). 
served before and after insulin treatment within the two groups of patients (autoantibody-positive and autoantibody-negative). FCP levels, before and after insulin treatment, were correlated positively in both subgroups $(\mathrm{rS}=0.88, \mathrm{P}<0.0001)$.

Beta cell function (HOMA $ß$ ) improvement by insulin treatment was observed in autoantibody-negative patients (before insulin: median, 7.3\%; range, $2.2-29.2 \%$ vs after insulin: median, $33.4 \%$; range, $8.0-135.4 \%$; $\mathrm{P}=0.0034)$, but not in autoantibody-positive patients (before insulin: median, 6.6\%; range, $1.8-262.7 \%$ vs after insulin: median, $20.9 \%$; range, 5.9-79.2\%) (Figure 2; Table 1). There was also a correlation between $\beta$ cell function, before and after insulin treatment, in autoantibody-negative patients $(\mathrm{rS}=0.84$, $\mathrm{P}=0.005)$, but not in autoantibody-positive patients.

When insulin sensitivity (HOMA S) was compared between autoantibody-positive and -negative patients after insulin treatment, it was higher in the former group (median, 149.7; range, 97.7-1354.0 vs median, 92.1; range, 32.3-475.6; $\mathrm{P}=0.026$, respectively). These results are shown in Table 1.

\section{Discussion}

The identification of diabetes type is sometimes difficult in non-obese adults aged 25 to 50 years $(18,19)$. A subset of these patients may develop OHAF more rapidly. In these OHAF patients initially classified as T2DM, many different etiopathogenic mechanisms can be involved. One third of these patients have a late-onset and slowly evolving autoimmunity against $B$ cells (latent autoimmune diabetes of the adult) (8) and others may have a dysfunction of $\beta$ cells and/or a decrease in insulin sensitivity induced by chronic hyperglycemia $(5,20)$.

This was a pilot study carried out to determine the presence of these factors in a group of lean diabetic patients with both primary and secondary OHAF, whose me- dian age was 41 years.

Our data indicate that a higher age at diabetes diagnosis was associated with a longer insulin-independent phase. Differently, Humphrey et al. (21) found that age at diagnosis did not correlate with the duration of the non-insulin-dependent phase. However, in the UK Prospective Diabetes Study (2), younger age was one of the factors related to higher failure of oral hypoglycemic agents or to shorter insulin-independent phase.

Ketonuria was present in $55.5 \%$ of our patients at first laboratory evaluation, in agreement with data indicating that ketosis is often associated with insulin deficiency (22). However, although ketonuria may indicate insufficient insulin action, it is not equal to insulin dependence. Insufficient insulin action may be due to either absolute insulin deficiency or severe insulin resistance (23). According to Hother-Nielsen et
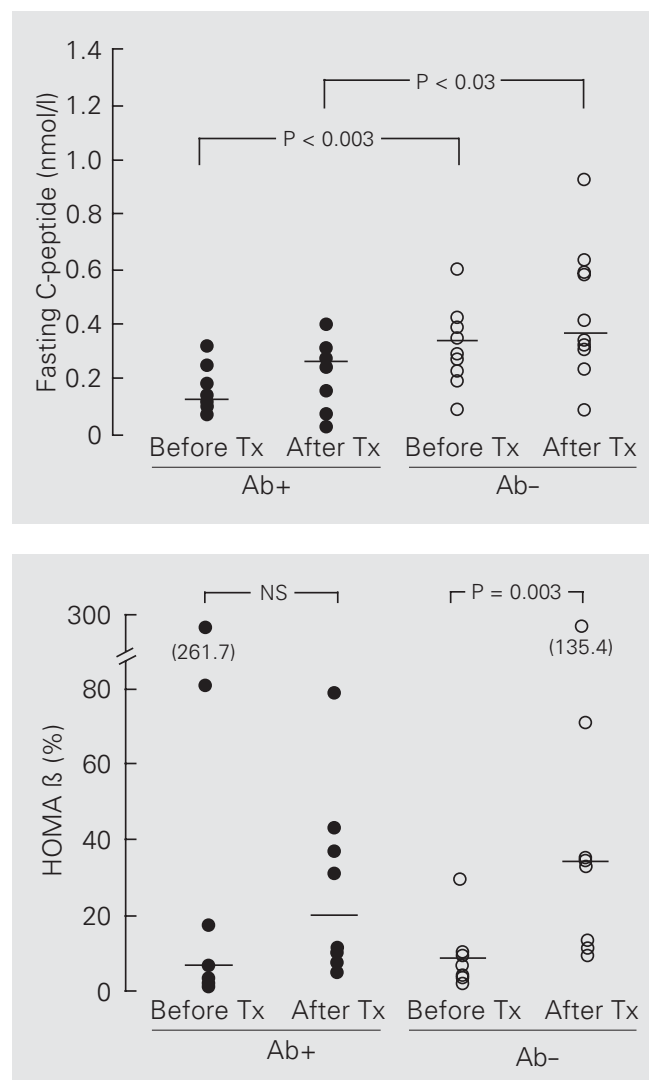

Figure 1. Comparison of fasting C-peptide (nmol/l) levels between autoantibody-positive $(\mathrm{Ab}+)$ and autoantibody-negative (Ab-) diabetic patients with oral hypoglycemic agent failure before and after insulin treatment $(T x)$. The statistical tests used were Mann-Whitney ranksum test and Wilcoxon signed rank test.

Figure 2. Comparison of homeostasis model assessment $B$ (HOMA ß) between autoantibody-positive $(\mathrm{Ab}+)$ and autoantibody-negative (Ab-) diabetic patients with oral hypoglycemic agent failure, before and after insulin treatment $(T x)$. The statistical tests used were MannWhitney rank-sum test and Wilcoxon signed rank test. NS = nonsignificant. 
al. (23), several non-insulin-requiring patients, with stimulated C-peptide values far above the discriminatory C-peptide level, can have ketonuria of considerable magnitude. The results of another study (24) also indicated a wide heterogeneity of clinical subtypes among patients who develop ketosis.

Glycemic control was poor at entry (median HbA1c: $11.7 \%$ ) and improved significantly after 24 weeks of insulin therapy (median HbA1c: 7.2\%), suggesting that the high glucose concentrations at entry could be responsible for $\beta$ cell desensitization. In another similar study, this level of metabolic control achieved after insulin treatment seemed to restore sensitivity to sulfonylurea by enhancing $\beta$ cell secretory activity in nonobese T2DM patients (25).

Serum C-peptide has been considered a valuable method of monitoring pancreatic $B$ cell function in diabetic patients, whether or not they are receiving insulin treatment (26), and therefore we chose this parameter for the present study. The $B$ cell function of our patients was heterogeneous, as suggested by the wide amplitude of variation of FCP both before and after insulin treatment. FCP levels before and after insulin treatment showed a good correlation.

In a previous study from our laboratory, we showed that classic T1DM and T2DM patients had a mean FCP value of $0.15 \pm 0.15$ and $0.69 \pm 0.29 \mathrm{nmol} / 1$, respectively, within the first 6 months of clinical diagnosis (27). FCP values for the total group of OHAF patients studied were intermediate between those of T1DM and T2DM. However, 44\% of our OHAF patients had FCP below 0.20 $\mathrm{nmol} / \mathrm{l}$ and they could be classified as insulin deficient according to the endocrine criteria used to separate T1DM from T2DM $(28,29)$. These data are similar to those obtained in another study that showed that about one third of non-insulin-dependent diabetic patients with secondary OHAF are permanently insulin deficient (30).

Humphrey et al. (21), however, observed that up to $40 \%$ of diabetic adults have equivocal C-peptide results at any post-diagnosis stage and that $\mathrm{C}$-peptide measurement alone may be of little utility in distinguishing between T1DM and T2DM. Glucagon-stimulated C-peptide levels have a poor negative predictive value for secondary OHAF in T2DM; indeed, less than $30 \%$ of the subjects with very low levels require insulin (31). So far, the decision to treat with insulin is usually made on clinical grounds and the cut-off value for hyperglycemia is not consensual (32).

HOMA (33), a structural computer model of the glucose-insulin feedback system, performs well in comparison with several tests of insulin sensitivity and $\beta$ cell function, including the hyperglycemic clamp, the oral glucose tolerance test and the intravenous glucose tolerance test. However, intrasubject variability of $30 \%$ in normal and diabetic subjects limits the interpretation of individual data. According to a recent study by Taverna et al. (32), HOMA $\beta$ is a better predictor of the insulin-requiring stage in long-standing T2DM patients with secondary OHAF than clinical indices, such as long duration of diabetes and/or elevated glycemic levels.

In the present study, we observed that both $\beta$ cell function and insulin sensitivity improved after the attenuation of the glucotoxic effect. It has been demonstrated that hyperglycemia can be improved by shortterm insulin therapy in T2DM patients (34). On the other hand, a recent study showed that the deficiency in glucose metabolism could rapidly return if insulin therapy is discontinued (35). Therefore, other mechanisms might be involved in the OHAF process.

One of these mechanisms could be slowly progressive autoimmune modifications. Concerning our patients, the positivity of GAD65Ab (33.3\%) and ICA (27.8\%) was higher than the percentage detected by other investigators in patients primarily classified 
as T2DM $(36,37)$. An explanation for this fact may be related to patient age, the criteria used to define primary and secondary OHAF and also to the fact that these were not obese patients. Furthermore, up to $2.4 \%$ of healthy subjects are positive for GAD65Ab (38).

Groop et al. (37) detected a $14 \%$ frequency of ICA-positive patients aged 35-75 years at diagnosis. However, these patients were older than those evaluated in our study. Concerning GAD65Ab, Niskansen et al. (38) found $9 \%$ positivity, but obese patients with a higher mean age were also included. In a study of young adult diabetic patients, Hagopian et al. (39) detected $21 \%$ positivity for GAD65Ab. Tuomi et al. (7), studying non-obese adult onset diabetic patients, found that one third of them probably corresponded to latent autoimmune diabetes of the adult, since $33 \%$ of them presented low C-peptide levels and $76 \%$ of them were GAD65Ab positive. Zimmet et al. (8) reported similar results for non-obese adult diabetic patients using insulin. Therefore, the percentage (44\%) of autoantibody positivity in our group is intermediate between that found in classic $\mathrm{T} 2 \mathrm{DM}$ and in latent autoimmune diabetes of the adult patients. This may suggest that autoimmunity does not totally explain the OHAF of our patients.

We cannot also totally exclude the possibility that the presence of autoantibodies against pancreatic $\beta$ cells in our patients represents an epiphenomenon. The autoantibodies are serological markers of T-cellmediated $\Omega$ cell destruction (38). They can also be released in response to the metabolic injury rather than being a primary event. It is known that high glucose concentrations can strongly stimulate the synthesis of GAD65, possibly exacerbating an autoimmune process (40).

When the clinical and metabolic characteristics of OHAF patients with and without autoantibodies were compared, it was observed that they did not differ in relation to sex, BMI, FPG or HbA1c levels, either be- fore or after insulin treatment. However, patients positive for autoantibodies tended to be younger than those negative for autoantibodies and early or primary sulfonylurea failure occurred in the majority of them (75\%), similar to data published by others (37).

Beta cell function and insulin sensitivity before and after a period of insulin therapy were also compared by HOMA in the two groups of OHAF diabetic patients (autoantibody-positive and autoantibody-negative subjects). It is important to emphasize that BMI was unchanged in the two groups, both before and after insulin therapy, providing more reasonable conditions for HOMA comparison. Beta cell function improved in autoantibody-negative patients after 24 weeks of insulin therapy, but not in autoantibodypositive patients. This suggests that there is a point of no return of $\beta$ cell function, which may be related to an autoimmune insulitis process in these autoantibody-positive OHAF diabetic patients. The improvement in $\beta$ cell function in the autoantibody-negative group could be due to a decrease in the grade of desensitization of $\beta$ cells to glucose. On the other hand, the insulin sensitivity after insulin treatment was better in the autoantibodypositive group than in the autoantibody-negative group. Interestingly, the $\beta$ cell function of autoantibody-positive OHAF patients after insulin treatment $(20.9 \%)$ was similar to that of the patients of the UK Prospective Diabetes Study (26.2\%) who progressed to insulin dependency after 6 years of diabetes (2).

The results of the present study are consistent with the pathogenetic heterogeneity of OHAF in lean adult non-insulin-dependent diabetic patients. Thus, autoimmunity against, or desensitization of, pancreatic $\beta$ cells can be found in a group of non-obese adult diabetics with OHAF.

Sometimes the phenotype of adult autoantibody-positive patients resembles that of autoantibody-negative patients. The pres- 
ence of autoantibodies against $\beta$ cells increases the likelihood of $\beta$ cell function deterioration, even after sustained improvement of glycemic control by means of insulin treatment.

Primary and secondary OHAF appear to separate autoantibody-positive and -nega- tive patients quite well. In addition, our data suggest that in autoantibody-negative patients with OHAF $\beta$ cell function may improve after a period of insulin therapy. However, the effects of this recovery on the restoration of sensitivity to oral hypoglycemic agents need to be studied further.

\section{References}

1. Simó R \& Hernandez C (2002). Tratamiento de la diabetes mellitus: objetivos generales y manejo en la práctica clínica. Revista Española de Cardiología, 55: 845-860.

2. Matthews DR, Cull CA, Stratton IM, Holman RR \& Turner RC (1998). UKPDS 26: Sulphonylurea failure in non-insulin-dependent diabetic patients over six years. UK Prospective Diabetes Study (UKPDS) Group. Diabetic Medicine, 15: 297-303.

3. Irvine WJ, McCallum CJ, Gray RS \& Duncan LJ (1977). Clinical and pathogenic significance of pancreatic islet-cell antibodies in diabetics treated with oral hypoglycaemic agents. Lancet, 1: 1025-1027.

4. Kobayashi T, Itoh T, Kosaka K, Sato K \& Tsuji K (1987). Time course of islet cell antibodies and ß-cell function in non-insulin dependent stage of type I diabetes. Diabetes, 36: 510-517.

5. Robertson RP, Harmon J, Tran PO, Tanaka Y \& Takahashi H (2003). Glucose toxicity in ß-cells: Type 2 diabetes, good radicals gone bad, and the glutathione connection. Diabetes, 52: 581-587.

6. Seissler J, de Sonnaville JJJ, Morgenthaler NG, Steinbrenner H, Glawe D, Khoo-Morgenthaler UY, Lan MS, Notkins AL, Heine RJ \& Scherbaum WA (1998). Immunological heterogeneity in type I diabetes: presence of distinct autoantibody patterns in patients with acute onset and slowly progressive disease. Diabetologia, 41: 891897

7. Tuomi T, Groop LC, Zimmet P, Rowley MJ, Knowles W \& Mackay IR (1993). Antibodies to glutamic acid decarboxylase reveal latent autoimmune diabetes in adults with a non-insulin-dependent onset of disease. Diabetes, 42: 359-362.

8. Zimmet P, Tuomi T, Mackay IR, Rowley MJ, Knowles W, Cohen M \& Lang DA (1994). Latent autoimmune diabetes mellitus in adults (LADA): the role of antibodies to glutamic acid decarboxylase in diagnosis and prediction of insulin dependency. Diabetic Medicine. 11: 299-303.

9. Evans JL, Goldfine ID, Madduk BA \& Grodsky GM (2002). Oxidative stress and stress-activated signaling pathways: a unifying hypothesis of type 2 diabetes. Endocrine Reviews, 23: 599-622.

10. De Fronzo R \& Simonson DC (1992). Glucose toxicity. In: Mazzaferri EL (Editor), Advances in Endocrinology and Metabolism/3. MosbyYear Book Inc., Chicago, IL, USA, 1-41.

11. The Expert Committee on the Diagnosis and Classification of Diabetes Mellitus (1997). Report of the Expert Committee on the diagnosis and classification of diabetes mellitus. Diabetes Care, 20: 1183-1197.

12. Seltzer HS (1980). Efficacy and safety of oral hypoglycemic agents. Annual Review of Medicine, 31: 261-272

13. Sá JR, Russo EMK, Miranda WL, Vieira JGH, Santiago RCM, Chacra AR \& Lourenço DM (1987). Comparação entre os métodos de cromatrografia de troca iônica e cromatografia de afinidade para a dosagem de hemoglobina glicosilada (HbA1c). Arquivos Brasileiros de Endocrinologia e Metabolismo, 31: 1-3.

14. Heding LG \& Munkgaard RS (1975). Human C peptide in normal and diabetic subjects. Diabetologia, 11: 201-206.

15. Dib SA, Colmann PG, Dotta F \& Eisenbarth GS (1987). Expression of cytoplasmic islet cell antigens by rat pancreas. Diabetes, 36: 982 985

16. Velloso LA, Kampe O, Hallberg A, Christmanson L, Betsholtz C \& Karlsson A (1993). Demonstration of GAD-65 as the main immunogenic isoform of glutamate decarboxylase in type I diabetes and determination of autoantibodies using a radioligand produced by eukaryotic expression. Journal of Clinical Investigation, 91: 2084 2090.

17. Levy JC, Matthews DR \& Hermans MP (1998). Correct Homeostasis Model Assessment (HOMA) evaluation uses the computer program. Diabetes Care, 21: 2191-2192.

18. Zimmet P, Turner R, McCarty D, Merril R \& Mackay I (1999). Crucia points at diagnosis. Type 2 diabetes or slow type 1 diabetes. Diabetes Care, 22: B59-B64.

19. Laakso M \& Pyorala K (1985). Age of onset and type of diabetes. Diabetes Care, 8: 114-117.

20. Leahy JL, Bonner-Weir S \& Weir G (1992). Beta cell dysfunction induced by chronic hyperglycaemia. Diabetes Care, 15: 442-445.

21. Humphrey ARG, McCarty DJ, Mackay IR, Rowley MJ, Dwyer T \& Zimmet P (1998). Autoantibodies to glutamic acid decarboxylase and phenotypic features associated with early insulin treatment in individuals with adult-onset diabetes mellitus. Diabetic Medicine, 15: 113-119.

22. Melton III LJ, Palumbo PJ \& Chu CP (1983). Incidence of diabetes mellitus by clinical type. Diabetes Care, 6: 75-86

23. Hother-Nielsen O, Faber O, Sorensen NS \& Beck-Nielsen H (1988). Classification of newly diagnosed diabetic patients as insulin-requiring or non-insulin-requiring based on clinical and biochemical variables. Diabetes Care, 11: 531-537.

24. Maldonado M, Hampe C, lyer D, Rajan A, Hammerle L, Lermark A \& Balasubramanyam A (2001). Clinical and biologic heterogeneity of diabetes presenting with ketoacidosis. Diabetes, 50 (Suppl 2): A262 (Abstract)

25. Torella R, Salvatore T, Cozzolino D, Giunta R, Quatraro A \& Giugliano D (1991). Restoration of sensitivity to sulfonylurea after strict glycemic control with insulin in non-obese type 2 diabetic subjects. Diabetes and Metabolism, 17: 443-447.

26. Hsich SD, Kanazawa Y \& Akanuma Y (1985). Serum free C-peptide response to oral glucose loading as a parameter for the monitoring of pancreatic B-cell function in diabetic patients. Diabetes Research and Clinical Practice, 1: 109-114. 
27. França AP, Maltez DL, Reis AF, Tavares E, Shiota D, Nasri F, Moisés RCS, Sá JR \& Dib SA (1997). Peptídeo-C de jejum na classificação dos diferentes tipos de diabetes mellitus. Arquivos Brasileiros de Endocrinologia e Metabolismo, 41: 26 (Abstract).

28. Laakso M, Ronnemaa T, Sarlund HH, Pyorala K \& Kallio V (1989). Factors associated with fasting and post-glucagon plasma C-peptide levels in middle-aged insulin-treated diabetic patients. Diabetes Care, 12: 83-88.

29. The DCCT Research Group (1986). The Diabetes Control and Complications Trial (DCCT): design and methodologic considerations for feasibility phase. Diabetes, 35: 530-545.

30. Peng YS \& Juang JH (1998). Effects of insulin therapy on noninsulin-dependent diabetics with secondary agent failure. Changgeng Yi Xue Za Zhi, 21: 271-276.

31. Scheen A, Castillo MS \& Lefebvre P (1996). Assessment of residual insulin secretion in diabetic patients using the intravenous glucagon stimulatory test: methodological aspects and clinical applications. Diabetes and Metabolism, 22: 397-406.

32. Taverna MJ, Pacher N, Bruzzo G, Slama G \& Selam JL (2001). Betacell function evaluated by HOMA as a predictor of secondary sulphonylurea failure in type 2 diabetes. Diabetic Medicine, 18: 584588.

33. Matthews DR, Hosker JP, Rudenski AS, Treacher DF \& Turner RC (1985). Homeostasis model assessment: insulin resistance and $ß-$ cell function from fasting plasma glucose and insulin concentrations in man. Diabetologia, 28: 412-419.

34. Yki-Jarvinen H, Esko N, Eero H \& Taskinni MR (1988). Clinical benefits and mechanisms of a sustained response to intermittent insulin therapy in type 2 diabetic patients with secondary drug failure. American Journal of Medicine, 84: 185-192.

35. Karvestedt L, Andersson G, Efendic S, Clauson P \& Grill V (1998). Improvement of $ß$-cell function by intensive insulin treatment is rapidly induced and rapidly lost. EASD'98, 34th Annual Meeting, Barcelona, Spain, September 8-12, Abstract 962.

36. Jennings AM, Spencer KM, Wilson RM, Botazzo GF \& Ward JD (1989). Islet cell antibodies and insulin autoantibodies in patients treated with oral hypoglycaemic agents. Diabetic Medicine, 6: 434439.

37. Groop LC, Botazzo GF \& Doniach D (1986). Islet cell antibodies identify latent type I diabetes in patients aged $35-75$ years at diagnosis. Diabetes, 35: 237-241.

38. Niskansen LK, Tuomi T, Karjalainen J, Groop LC \& Uusitupa MIJ (1995). GAD antibodies in NIDDM. Ten-year follow-up from the diagnosis. Diabetes Care, 18: 1557-1565.

39. Hagopian WA, Karlsen AE, Gottsater A, Landin-Olsson M, Grubin CE, Sundkvist G, Pedersen JS, Boel E, Dyberg T \& Lernmark $\AA$ (1993). Quantitative assay using recombinant human islet glutamic acid decarboxylase (GAD65) shows that 64K autoantibody positivity at onset predicts diabetes type 1. Journal of Clinical Investigation, 91: 368-374.

40. Bjork E, Kampe O, Karlsson FA, Pipeleers DG, Andersson A, Hellerstrom C \& Eizirik DL (1992). Glucose regulation of the autoantigen GAD65 in human pancreatic islets. Journal of Clinical Endocrinology and Metabolism, 75: 1574-1576. 